\title{
Determinants of Deposit Mobilization in the Case of Commercial Bank of Ethiopia Selected Branches
}

\author{
Getaneh Yenealem Ayene \\ Department of Accounting and Finance, Debre Markos University \\ PO box 269, Debre Markos, Ethiopia
}

\begin{abstract}
Deposit mobilization is among one of the primary activities of banking system. Banks mobilize financial resource required for investment and economic growth from households, business, corporate bodies and government. To be effective, competitive in the market and maintain liquidity identifying factors affecting deposit mobilization is crucial. With this in mind the objective of this study is to identify determinants of bank deposit mobilization in the case of Commercial Bank of Ethiopia. To achieve this objective primary data collected through distributing 238 valid questionnaires to selected customers of the bank is primarily used. To complement primary data, secondary data is also used to some extent. Data analysis is handled quantitatively through the help of SPSS. The study findings shows that branch expansion, variety of services offered by the bank, confidentiality of customer information, trust on banking system and saving habits are found to be significant variables affecting deposit mobilization. More over interest rate and inflation are also among significant macroeconomic factors affecting deposit mobilization. Based on these findings recommendations are also forwarded.
\end{abstract}

Keywords: Bank Deposit, Commercial Banks

DOI: $10.7176 / \mathrm{EJBM} / 12-13-04$

Publication date:May $31^{\text {st }} 2020$

\section{Introduction}

Banks play a key role in improving economic efficiency through channeling funds from resource surplus unit to those with better productive investment opportunities. They mobilize funds in the form of deposit from households, institutions and government entities and bank deposit represent the most significant components of the money supply used by the public (Mishkin and Eakins, 2012).

Deposit mobilization activity is among the corner stone of the depository financial institutions and area of competition for the sector. With the money mobilized financial institutions provide direct loan to various entities and invest in securities; earn interest and investment income, too. (Fabozi et al, 2010). In less monetized countries, like Ethiopia, effective and efficient functioning of the deposit mobilization has significant role in facilitating economic growth.

Currently in Ethiopia commercial banks, among deposit taking institutions have a lion share in deposit mobilization and they are the main creditors of the corporate bodies, individual investors and government. As of year 2017/18 a total of 18 (eighteen) banks were in operation in Ethiopia. (NBE, 2018). Most of business organizations highly depend on bank loans as a source of capital. The ability of banks in providing loan depend much on their ability to attract deposits. To be competitive enough in the banking sector a bank should have a good share in the deposit market. Mobilizing deposits will be ineffective without knowing and controlling factors affecting it. Thus, it is worthwhile to conduct a study on determinant factors of deposit mobilization.

\section{Statement of the Problem}

In any country, commercial banks play vital role in the economy through mobilizing financial resources to finance priorities of the economy. In the context of Ethiopia, the amount of deposit mobilized is not sufficient to meet the amount of fund the economy requires. This is partly due to the stage of the banking system in the country. In Ethiopia, we do have only 4,757 number of bank branches serving a population of 106 million at countrywide. (NBE, 2018). Most of the branches are operating in Addis Ababa, regional and zonal cities which shows bank accessibility is still low. Because of this, there are still large number of rural and less-urban area residents who maintain savings in traditional way.

Accessibility could be one reason because over years as the number of branches increase deposit has also increased. (NBE 2017 and NBE, 2018). It is clear that with this small deposit only small portion of debtors' interest will be met. So identifying factors that affect deposit mobilization is crucial to the successful operation of banking business.

Few studies conducted so far in the issue of deposit mobilization indicated different bank specific and macroeconomic factors. (Erna and Ekki, 2004, Ferrouhi, 2017, Shemsu,2015, Mamo, 2017, ). The study results are inconclusive. In addition, prior studies primarily depend on secondary data. Additionally there were variables not taken in to account. Therefore, additional studies are required through considering primary data, and introducing new variables. This study will fill this gap. 


\section{Objectives of the study}

The overall objective of this study is to identify factors affecting bank deposit mobilization. More specifically, it achieves the following objectives.

* To identify internal factors affecting deposit.

* To assess the effect of external factors on deposit.

\section{Hypothesis of the study}

Based on literatures reviewed the following hypotheses were developed and tested

Ho1: Bank specific variables have no significant effect on deposit mobilization.

Ho2: Macroeconomic variables have no significant effect on deposit mobilization.

Ho3: Customer specific variables have no significant effect on deposit mobilization.

Ho4: Significant Deposit determinant variables do have the same effect across depositors with different demographic characteristics.

The remaining section of this report consists of review of related literature, research methods, findings and recommendations forwarded.

\section{Literature Review}

According to the Keynesian theory of demand for money, people hold money for three motives: transactions, precautionary and investment motives. In order to cater for these motives, commercial banks offer three categories of deposit facilities that are demand, savings and time deposits. Bank deposits represent the most significant components of the money supply used by the public, and changes in money growth are highly correlated with changes in the prices of goods and services in the economy. (Howells and Bain 2007).

Bank deposits are major liabilities for commercial banks. Banks use the deposit mobilized to get either interest income from loan or investment returns. Therefore, the higher the deposits, the higher will be the funds at the disposal of a bank to lend and earn profits. (Fabozzi et al, 2010). Deposits are a foundations up on which banks thrive and grow and unique items on a bank's balance sheet that distinguish them from other type of business organizations. Deposit is inexpensive as compared to non-deposit based funding for banks. (Saunders and Cornett, 2008) Commercial banks compete for deposits in order to become profitable and be able to supply more funds to the public. (Devinaga, 2010). It is also provides most of the raw materials for bank loans and thus represent the ultimate source of the bank's profits and growth.

An important indicator of the success and efficiency of any credit agency, like banks, is the amount of savings mobilized from the community in the form of deposit. However, deposit mobilization is very difficult task. It depends up on various factors internal or endogenous and external or exogenous to the banking system (Desinga, 1975).

\subsection{External factors}

The external factors are variables that are beyond the bank management but reflect the economic and legal environment that affects the operation and deposit positions of banks and these factors are discussed below.

\subsubsection{Interest Rate}

Depository institutions mobilize financial resources from economically surplus units and pay interest in return. The attraction for getting the deposit from the surplus sector is interest payment, which must be reasonable and acceptable to the owner of the money. Empirically, interest rate is found to be one of the important determinant factor to mobilize deposit in banking system (Mohammad and Mahdi, 2010, Herald and Heiko,2009). Interest rate is an encouraging factor for depositors. (Erna and Ekki, 2004 and Mustafa and Sayera, 2009). Erna and Ekki (2004) also argue that deposit to bank is attractive if the opportunity cost of holding cash in hand is high. Mohammad and Mahdi (2010) mentioned people withdraw their resources from banking system unless interest exceeds the inflation rate to prevent loss of value.

On the other hand, findings of Ghafur, 2003, and Mamo 2017, show that the rate of interest does not have influence to induce deposit mobilization in the bank. This contradicting result further encourages additional research

\subsubsection{Inflation}

The classical belief is since bank assets and liabilities are expressed in monetary terms and assets will normally grow in line with growth in money supply, banks are relatively immune from the effects of inflation (Devinaga, 2010).

In brief, monetary policy works by controlling the cost and availability of credit. During inflation, a central bank can raise the cost of borrowing and reduce the credit creating capacity of commercial banks. According to Devinga (2010), this will make borrowing more costly than before and thereby the demand for funds will be reduced. Similarly with a reduction in their credit creating capacity, the banks will be more cautious in their lending policies. Since the banks demand for fund decreases obviously the deposits will decrease. That is as inflation rate 
increases, true yield rate of money and assets decrease; therefore deposits are no longer attractive. (Mohammad and Mahdi, 2010)

A study by Mohammad and Mahdi, 2010, reveled the effect of inflation on savings and time deposit is significantly negative. It also negative affect the performance of financial sector through the market credits and in turn, on the performances of banks and capital markets and finally on the long term economic growth.

During inflationary situation savings lose value in proportion with money value decreases thus people prefer to change their cashes and savings to more reliable and stable forms such as land, jewelry, antiques, art collections, foreign currencies that causes to definite decrease in commercial bank's total deposit.(Mohammad and Mahdi, 2010).

\subsubsection{Per capita income of the society}

According to Jim (2008), per capita is the level of GDP divided by the population of a country or region. Changes in real GDP per capita over time are a measure of changes in the average standard of living of a country. Per capital income is expected to have a positive effect on deposits. A study by Epaphra, 2014, indicates higher incomes enhance the saving's ability of households and consequently raises the national savings.

\subsection{Internal Factors}

Internal factors are factors that are related to internal efficiencies and managerial decisions of a bank. They are also called bank specific factors.

\subsubsection{Liquidity of the banks}

Liquidity in banking system comprises of liquidity of financial instruments in the financial market (which shows smooth transactions with no barriers) and liquidity related to solvency (the obligation of banks to make payments to third parties). (Saunders and Cornett, 2008). The banks' liquidity management involves acquiring sufficient liquid asset to meet the bank's obligation to depositors and demand for loan.

Banks accept funds from depositors and extend such funds to the real sector while providing liquidity for any withdrawal of deposits. Individuals, businesses and government will be willing to deposits their money in banks if they are certain that they are safe to withdraw the money whenever they want, this is the question of liquidity of banks. Thus, more liquid banks can attract more deposits. (Herald and Heiko, 2009). If banks get illiquid, depositors will rash to withdraw their money, which leads to bank run and loss of trust on the banking system.

\subsubsection{Number of Branches}

Branch expansion decision takes in to account factors like deposit potential, level of competition, regional income. On the other side accessibility to customers also another factor for customers to choose the bank for deposit. Thus branching helps banks to expand their customer base across different geographic area. In empirical literature Erna and Ekki (2004), mentioned a long run relationship between commercial bank branch and commercial banks deposits. Shemsu (2015) and Mamo (2017) found that branch expansion is significant variable to affect deposit mobilization. However, findings in Bangladesh shows branch expansion have insignificant effect on bank deposit. (Nahidul, Julfikar and Wafik, 2019).

\section{Methodology of the study}

\subsection{Data Source and Method of Collection}

For this study, a descriptive research design was employed. Primary data collected through structured questionnaire is primarily used for analysis. Likert type questions were developed to collect data about each variables identified for the study. In addition, secondary data collected from annual reports of Commercial Bank of Ethiopia and annual reports of National Bank of Ethiopia were also used

\subsection{Sampling Design}

To meet the objective of the study data were collected from customers of Commercial Bank of Ethiopia (CBE). The target population of the study includes saving account holders of selected city and outline CBE branches under the domain of Bahir Dar District excluding current account holders who does not bear interest.

In Ethiopia, as of 2018, 18 banks are in operation. Among existing banks, Commercial Bank of Ethiopia has $62 \%$ share of deposit market. (NBE, 2018). Thus, it is worthwhile to take samples from Commercial Bank of Ethiopia to identify factors affecting deposit.

Multistage sampling was used for this study. First of all bank branches in Bahir Dar District were grouped to two strata; city and outline branches. During the study period, there were 80 branches in Bahir Dar District, of which 16 branches were city branches located in Bahir Dar and Debre Markos Town. Whereas, 64 branches were out-line branches found outside Bahir Dar and Debremarkos Towns. For the purpose of this study 2 branches from city (Abma and Ghion) and 3 branches from outline (Yejubie, Amanuel and Debre Work) are taken purposively based on their total customers, accessibility, availability of information, the representativeness of the nearby branches and at least 5 years of service.

To select respondents from selected branches of Commercial Bank of Ethiopia random sampling methods 
was applied. In selected five branches, there were about 83,860 customers, of which 67,927 were active saving account holders. The proportion of active account holders were about $81 \%$ which is computed as a ratio of 67,927 to 83,860 . Therefore, as mentioned by Kothari (2004), for proportions the sample size could be determined using the following formula.

Where,

$$
\mathrm{n}=\frac{\mathrm{z}^{2} \cdot \mathrm{p} \cdot(1-\mathrm{p})}{\mathrm{e}^{2}}
$$

$\mathrm{n}=$ number of sample size

$\mathrm{z}=\mathrm{Z}$-score in normal distribution at specific confidence level.

$\mathrm{p}=$ Proportion of active account holders

$\mathrm{e}=$ sampling error.

$$
\mathrm{n}=\frac{(1.96)^{2} \cdot 0.81 \cdot(1-0.81)}{(0.05)^{2}}=237
$$

To compensate for questionnaires that will be come invalid additional 13 respondents were considered therefore the sample size is adjusted to 250 .

Then after proportionate number of respondent were taken from each branch to distribute survey questioners. Accordingly $34 \%$ of respondents were from city branches and $66 \%$ from outline i.e. 85 from city Branches/ Abma and Ghion / and the rest 165 from outline /Yejubie, Amanuel and Debre Work branches/.

\subsection{Description of Variables}

Based on literature factors affecting deposit mobilization are grouped to two groups of variables namely internal factors and external factors (which consists of macro-economic and demographic variables).

Table 1: Variable description and measurement

\begin{tabular}{|l|l|l|}
\hline \multicolumn{1}{|c|}{ Variables } & \multicolumn{1}{|c|}{ Indicators } & \multicolumn{1}{c|}{ Measurement } \\
\hline Internal Factors & $\begin{array}{l}\text { - Accessibility (branch expansion) } \\
\text { - Confidentiality } \\
\text { - Varieties of service }\end{array}$ & Likert-type questions \\
\hline Macro-economic factors: & $\begin{array}{l}\text { - Interest rate } \\
\bullet \text { Inflation }\end{array}$ & Likert-type questions \\
\hline Customer Specific Variables & $\bullet$ Saving habit \\
& $\bullet$ Trust of the society in CBE & Likert-type questions \\
\hline
\end{tabular}

Once significant variables have been identified the researcher tries to see whether this significant variables varies among customers with different demographic characteristics. For this purpose age, marital status, occupation, level of education, and years as customer of CBE were taken in to account.

\subsection{Data analysis method}

The data collected through questionnaire is analyzed using descriptive statistical technique and inferential statistics. To show how each variable behaves a descriptive statistics is presented followed by t-test to measure level of significance.

\section{Findings of the study}

In this section finding of the study is presented using different statistical tools. Data analysis is based on data collected through valid 238 questionnaires and secondary data collected from annual reports.

\subsection{Demographic Characteristics of Respondents}

Before conducting hypothesis testing, a frequency distribution is presented for demographic variables of respondents as follows. In the study a total of 250 respondents participated from five branches, which were randomly selected from the total 80 Branches of CBE Bahir Dar District. Of the total 250 distributed survey questionnaires, 238(95.2\%) were successfully returned and found valid to make further analysis of the study.

Table 2. Distribution of respondents across selected Branches

\begin{tabular}{|r|r|r|r|r|r|r|}
\hline \multirow{2}{*}{ No. of questionnaires' } & \multicolumn{7}{|c|}{ Branch } \\
\cline { 2 - 7 } & Ghion & Abma & Amanuel & Debrework & Yejubie & Total \\
\hline Distributed & 65 & 50 & 46 & 46 & 43 & 250 \\
\hline Valid & 61 & 48 & 45 & 45 & 49 & 238 \\
\hline
\end{tabular}

Source: Computed from survey, 2018 .

\subsubsection{Age of respondent households}

Age is an indicator of the composition of productive and nonproductive groups of a society. Countries who have productive age group do have a more earning and saving potential Accordingly $31 \%(74)$ of the respondents were 
aged below 25 years old, $51 \%$ ( 121) of them were $26-40$ years old, $12 \%$ (28) of them are 41-50 years old and $6 \%(15)$ of them are 51 and above. Overall majority of respondents more than $50 \%$ were aged 25 to 40 years old, which implies most of them were adult, and in productive age.

Table3: Age of respondents

\begin{tabular}{|ll|r|r|r|r|}
\hline & Frequency & Percent & Valid Percent & Cumulative Percent \\
\hline & $<25$ years & 74 & 30.1 & 31.1 & 31.1 \\
& $26-40$ & 121 & 49.2 & 50.8 & 81.9 \\
Valid & $41-50$ & 28 & 11.4 & 11.8 & 93.7 \\
& $>50$ & 15 & 6.1 & 6.3 & 100.0 \\
& Total & 238 & 96.7 & 100.0 & \\
Missing & System & 8 & 3.3 & & \\
Total & 246 & 100.0 & & \\
\hline
\end{tabular}

Source: Computed from survey, 2018.

\subsubsection{Marital status of respondents}

The marital status of respondents is one of the main factors, which has an economic meaning as determinant factors on deposit mobilization. Those who are married and unmarried likely to have different earning potential, disposable income and that of savings. For easy of discussion the marital status of respondents is grouped to two categories, married and unmarried. Those respondents who are single, divorced and windowed are grouped as unmarried. As it is presented below in Table 4 majority of respondents about $65 \%$ were married.

Table 4: Marital Status of respondents

\begin{tabular}{|ll|r|r|r|r|}
\hline & & Frequency & Percent & Valid Percent & Cumulative Percent \\
\hline \multirow{3}{*}{ Valid } & Unmarried & 82 & 33.3 & 34.5 & 34.5 \\
& Married & 156 & 63.4 & 65.5 & 100.0 \\
& Total & 238 & 96.7 & 100.0 & \\
Missing & System & 8 & 3.3 & & \\
Total & 246 & 100.0 & & \\
\hline
\end{tabular}

Source: Computed from survey, 2018.

\subsubsection{Major occupation of respondents}

Recently, economic inequality among citizens has become widen from time to time and the effect of this inequality is highly observable in urban settings relative to rural areas. Partly this income inequality is associated with variety of occupation of individuals.

Large proportions of respondents, as presented in Table 5, were employees of government (about 55\%). This will be due to reasons one of which is in developing countries like Ethiopia where the capacity and development of private sectors is very limited, government is still considered as the first employer. In addition, Ethiopian government makes payroll payment via government bank so that employees are required to open saving account in commercial Bank of Ethiopia.

Now a days habit of using bank is changing because of that students' family transfer funds to cover tuition and living costs through banks. The findings of this study also show that $20 \%$ of respondents were students, second larger proportion next to government employees. On the other hand city residents, including Bahir Dar and Debre Markos, showed a gradual paradigm shift to start own business rather than being an employee of a government. Of the total respondents considered in this study, $16 \%$ of respondents were self-employed and the remaining respondents were retired and unemployed respondents.

Table 5: Type of occupation

\begin{tabular}{|ll|r|r|r|r|}
\hline & Frequency & Percent & Valid Percent & Cumulative Percent \\
\hline \multirow{6}{*}{ Valid } & 7 & 2.8 & 2.9 & 2.9 \\
& Student & 50 & 20.3 & 21.0 & 23.9 \\
& Retired & 12 & 4.9 & 5.0 & 29.0 \\
& Government Employee & 131 & 53.3 & 55.0 & 84.0 \\
& Self Employed & 38 & 15.4 & 16.0 & 100.0 \\
& Total & 238 & 96.7 & 100.0 & \\
Missing & System & 8 & 3.3 & & \\
Total & 246 & 100.0 & & \\
\hline
\end{tabular}

Source: Computed from survey, 2018.

\subsubsection{Education status of the respondents}

Many studies usually treat level of education of the respondent as key variable since it can play major role to 
determine the socio-economic situation and level of awareness of a given society.

From the total respondents, $2.1 \%$ were illiterate, $25.6 \%$ completed primary education, $29.4 \%$ completed secondary school, 22.3\% have college diploma and the remaining $20.6 \%$ have a qualification of first degree. In general speaking, majority of respondents were literate who can read and write.

Table 6: Level of education

\begin{tabular}{|ll|r|r|r|r|}
\hline & Frequency & Percent & Valid Percent & Cumulative Percent \\
\hline & Illiterate & 5 & 2.0 & 2.1 & 2.1 \\
& Primary Education & 61 & 24.8 & 25.6 & 27.7 \\
Valid & Secondary Education & 70 & 28.5 & 29.4 & 57.1 \\
& Diploma & 53 & 21.5 & 22.3 & 79.4 \\
& First Degree & 49 & 19.9 & 20.6 & 100.0 \\
& Total & 238 & 96.7 & 100.0 & \\
Missing & System & 8 & 3.3 & & \\
Total & 246 & 100.0 & & \\
\hline
\end{tabular}

Source: Computed from survey, 2018.

\subsubsection{Duration of Respondents as Customer}

The study also solicited from the customer respondents as how long they have been customer's of Commercial Bank of Ethiopia. The duration could tell us to what extent the data collected from customers' worth for the study. Table 7 shows that, only $27 \%$ of respondents were customers of the bank for less than three years. Majority about $73 \%$ of them have been a customer of Commercial Bank of Ethiopia for more than three years. This indicates that customers relatively stay for longer period and the bank has still good number of new customers.

Table 7: years as customer of the bank

\begin{tabular}{|ll|r|r|r|r|}
\hline & & Frequency & Percent & Valid Percent & Cumulative Percent \\
\hline \multirow{4}{*}{ Valid } & 3 years & 63 & 25.6 & 26.5 & 26.5 \\
& 3-12 years & 138 & 56.1 & 58.0 & 84.5 \\
& Total & 37 & 15.0 & 15.5 & 100.0 \\
Missing & System & 238 & 96.7 & 100.0 & \\
Total & 8 & 3.3 & & \\
\hline
\end{tabular}

Source: Computed from survey, 2018.

\subsection{Test of Internal Reliability}

Test of reliability measures whether the data collection instrument can create reproducible result. To this end, Cronbach's alpha coefficient estimate was assessed, which is commonly used test of internal reliability as mentioned by Bryman, 2012. A Cronbach alpha value of at least $70 \%$ insures existence of reliability of data collection instrument. The result of the test shows a value of 0.891 , which is more than the threshold, thus data collection instrument is found to be satisfactory. (see Table 8)

Table 8 Reliability Test

Case Processing Summary

\begin{tabular}{|ll|r|r|}
\hline & & $\mathrm{N}$ & \multicolumn{1}{c|}{$\%$} \\
\hline \multirow{3}{*}{ Cases } & Valid $^{*}$ & 238 & 96.7 \\
& Excluded $^{\mathrm{a}}$ & 8 & 3.3 \\
& Total & 246 & 100.0 \\
\hline
\end{tabular}

a. Listwise deletion based on all variables in the procedure.
Reliability Statistics

\begin{tabular}{|r|r|}
\hline Cronbach's Alpha & N of Items \\
\hline .891 & 7 \\
\hline
\end{tabular}

\subsection{Test of Hypothesis Result}

Three groups of variables have been identified to have an effect on deposit mobilization activity of Commercial Bank of Ethiopia; namely bank specific factors, macroeconomic variables and customers related variables. One sample t-test is conducted to check whether these factors do have an effect on deposit and the result is presented below in line with hypothesis to be tested.

For all variables a likert type questions, with five-likert scale ranging from Strongly Disagree to Strongly Agree, were developed to address the effect of each variable. A respondent who disagrees with the issue raised will select either 1 or 2 , and a one who agree chooses will select either 4 or 5 . If a respondent found to be indifferent a respondent selects 3 . Thus the 'neutral, response shows the respondent is indifferent to conclude either to agree/disagree. Because of this, a score of 3 has served as a bench mark to test the level of significance for each variable using one sample t-test. 
Ho1: bank specific variables have no significant effect on deposit mobilization.

On of bank specific variables considered for this study is branch expansion, it was found to be one of significant variable in prior studies conducted by Shemsu, 2015 and Mamo, 2017. However, findings in Bangladesh shows branch expansion have insignificant on bank deposit. (Nahidul, Julfikar and Wafik, 2019).

The result in Table 9 shows the mean score of branch expansion is 3.43 and it is found to be significant at $5 \%$ level of significance. Which is consistent with the results of Erna and Ekki (2004), Shemsu (2015) and Mamo (2017).

Variety of services offered by a bank is also another factor for which customers open and keep saving accounts. The mean score for this variable is 3.87 and it is found to be significant variable to affect deposit. /see table $9 \& 10$ below/. The third variable included among bank specific variables is the extent to which a bank keeps banking history of depositors'. The mean score of confidentiality of customers' information is 4.06 and it is found to be significant. Which means depositors give due attention for this variable.

Table 9: One-Sample Statistics

\begin{tabular}{|l|r|r|r|r|}
\hline & \multicolumn{1}{|c|}{$\mathrm{N}$} & \multicolumn{1}{|c|}{ Mean } & Std. Deviation & Std. Error Mean \\
\hline Branch Expansion & 238 & 3.43 & .877 & .057 \\
Verities of Services & 238 & 3.87 & .436 & .028 \\
Confidentiality of customer & 238 & 4.0588 & .43660 & .02830 \\
information & & & \\
\hline
\end{tabular}

Source: SPSS result from survey, 2018.

Among the three significant variables depositors rate most confidentiality of their information, followed by variety of services offered and accessibility. According to the National Bank of Ethiopia Annual Report, Commercial Bank of Ethiopia opened 65 new branches over the year 2017/18 throughout the country. (NBE, 2018). This is a good progress in improving bank accessibility and deposit mobilized however; this study result shows that branch expansion should not be the only concern for successful deposit mobilization as it is rated third in Table 9.

Table 10: One-Sample Test

\begin{tabular}{|c|c|c|c|c|c|c|}
\hline & \multicolumn{6}{|c|}{ Test Value $=3$} \\
\hline & \multirow[t]{2}{*}{$\mathrm{T}$} & \multirow[t]{2}{*}{$\mathrm{df}$} & \multirow[t]{2}{*}{$\begin{array}{l}\text { Sig. (2- } \\
\text { tailed) }\end{array}$} & \multirow[t]{2}{*}{$\begin{array}{c}\text { Mean } \\
\text { Difference }\end{array}$} & \multicolumn{2}{|c|}{$\begin{array}{l}95 \% \text { Confidence Interval of the } \\
\text { Difference }\end{array}$} \\
\hline & & & & & Lower & Upper \\
\hline Branch Expansion & 7.610 & 237 & $.000 * *$ & .433 & .32 & .54 \\
\hline Verities of Services & 30.806 & 237 & $.000 * *$ & .870 & .81 & .93 \\
\hline $\begin{array}{l}\text { Confidentiality of customer } \\
\text { information }\end{array}$ & 37.414 & 237 & $.000 * *$ & 1.05882 & 1.0031 & 1.1146 \\
\hline
\end{tabular}

Source: SPSS result from survey, 2018. significance.

**Significant at $5 \%$ level of

Ho2: macroeconomic variables have no significant effect on deposit mobilization.

Ferrouhi, 2017, a study on deposit determinants in Morocco, showed that deposit is positively correlated with interest rate on deposit. Nahidul et al, 2019, on the other hand found deposit interest rate have no significant impact on deposit. In addition, a study in Ghana, by Larbi and Angmor, 2015, indicates a significantly negative shortterm impact of inflation on deposit. For this study, both interest rate and inflation rate were considered among macro-economic variables affecting deposit.

The policy measures taken by National Bank of Ethiopia in October 2017 to increase the minimum and maximum deposit interest rates to 7.0 and 9.0 percent from 5.0 and 5.75 percent is expected to have a positive impact on deposit mobilization of depository institutions. As a result of this decision the average saving deposit rate for fiscal year 2017/18 was 8.0 percent. (NBE, 2018). However, the interest rate was still less than the inflation rate. Inflation has also shown an increment from 8.8 to 14.7 percent from prior year. This leads to a negative real interest rate of 6.7 percent. Unless the real rate is positive deposit for interest income is not attractive. Which is also true in this study. (See Table 12 below)

The paradox is though real interest rate goes down as compared to last year, the National Bank of Ethiopia reports an annual deposit growth of 28.4 percent from prior year. This might be attributable to 500 newly opened branches at country level. (NBE, 2018). In addition, the result implies customers deposit for a reason other than interest income. Because had it been income, they will not deposit to loss value.

Table 11: One-Sample Statistics

\begin{tabular}{|l|r|r|r|r|}
\hline & \multicolumn{1}{|c|}{$\mathrm{N}$} & \multicolumn{1}{c|}{ Mean } & Std. Deviation & Std. Error Mean \\
\hline Interest rate & 238 & 3.89 & .508 & .033 \\
Inflation & 238 & 2.1218 & .55676 & .03609 \\
\hline
\end{tabular}


As presented in Table $11 \& 12$, interest rate encourages deposit however inflation did not. The mean score for interest rate and inflation is 3.89 and 2.12 respectively. One sample t-test result in Table 12 also shows that interest rate and inflation do have positive and negative effect on deposit mobilization, respectively. Thus, the null hypothesis is rejected and it found that interest rate and inflation rate are significant variables.

Table 12: One-Sample Test

\begin{tabular}{|c|c|c|c|c|c|c|}
\hline & \multicolumn{6}{|c|}{ Test Value $=3$} \\
\hline & \multirow[t]{2}{*}{$\mathrm{T}$} & \multirow[t]{2}{*}{ df } & \multirow[t]{2}{*}{ Sig. (2-tailed) } & \multirow[t]{2}{*}{ Mean Difference } & \multicolumn{2}{|c|}{$95 \%$ Confidence Interval of the Difference } \\
\hline & & & & & Lower & Upper \\
\hline Interest rate & 27.051 & 237 & $.000 * *$ & .891 & .83 & .96 \\
\hline Inflation & -24.333 & 237 & $.000 * *$ & -.87815 & -.9492 & -.8071 \\
\hline
\end{tabular}

Source: SPSS result from survey, 2018.

**Significant at $5 \%$ level of significance.

Ho3: Customer specific variables have no significant effect on deposit mobilization.

Customer specific variables are not taken in to account as factors affecting deposit mobilization in most of the studies conducted so far. The inclusion of these variables is among the unique features of the study. Among customer specific factors, trust as service provider and saving habit of customers were considered.

Table 13: One-Sample Statistics

\begin{tabular}{|l|r|r|r|r|}
\hline & $\mathrm{N}$ & \multicolumn{1}{|c|}{ Mean } & \multicolumn{1}{c|}{ Std. Deviation } & \multicolumn{1}{c|}{ Std. Error Mean } \\
\hline Trust as service provider & 238 & 3.92 & .546 & .035 \\
Saving culture & 238 & 3.65 & .801 & .052 \\
\hline
\end{tabular}

Source: SPSS result from survey, 2018.

Table 13 above shows that the mean score of customers' trust and saving habit is 3.92 and 3.65 respectively. In addition, both variables found to be significant at 5\% level of significance. /see Table 14/.

Table 14: One-Sample Test

\begin{tabular}{|c|c|c|c|c|c|c|}
\hline & \multicolumn{6}{|c|}{ Test Value $=3$} \\
\hline & \multirow[t]{2}{*}{$\mathrm{t}$} & \multirow[t]{2}{*}{$\mathrm{df}$} & \multirow[t]{2}{*}{$\begin{array}{l}\text { Sig. (2- } \\
\text { tailed) }\end{array}$} & \multirow[t]{2}{*}{$\begin{array}{c}\text { Mean } \\
\text { Difference }\end{array}$} & \multicolumn{2}{|c|}{$\begin{array}{l}\text { 95\% Confidence Interval of the } \\
\text { Difference }\end{array}$} \\
\hline & & & & & Lower & Upper \\
\hline $\begin{array}{l}\text { Trust as service } \\
\text { provider }\end{array}$ & 26.121 & 237 & $.000 * *$ & .924 & .85 & .99 \\
\hline Saving culture & 12.543 & 237 & $.000 * *$ & .651 & .55 & .75 \\
\hline
\end{tabular}

Source: SPSS result from survey, 2018.

**Significant at $5 \%$ level of significance.

Ho4: deposit determinant variables do have the same effect across depositors with different demographic characteristics.

To test this hypothesis analysis of variance /ANOVA/ is employed. The issue here is whether the effect of bank specific, macroeconomic and customer specific factors vary across different age, marital status, level of education, occupation groups of depositors. All other things remaining the same, the effect of macroeconomic variables on deposit is expected to be the same among individuals as they are not individuals specific.

Among bank specific variables, branch expansion, confidentiality of information and variety of service found to be significant as presented above in Table 10. When we look at the effect of each variables among different individual depositors, the effect of branch expansion on deposit varies among individuals with different age group (Table 15 in appendix), different occupation (Table 17 in appendix), different level of education (Table in appendix 18) and different years as customer (Table 19 in appendix). On the other hand, the effect of ability of the bank to keep customers information confidentially on deposit varies among individuals with different age groups (see Table 15), marital status(see Table 16), level of education(see Table 18), and different years as customers(see Table 19). Moreover the effect of variety of services offered by banks on deposit varies among individuals with different marital status (see Table 16), occupation (see Table 17), and different level of education (see Table 18).

In table 14 trust on banking system and saving culture of depositors' are found to be significant. Of the two variables, the effect of trust on banking system varies depending on depositors' demographic characteristics. Specifically the effect of trust on banking system varies depending on age group(see Table 15), marital status (see Table 16), occupation (see Table 17), level of education (see Table 18), and years as bank customer(see Table 19). Among all variables taken in to account the effect of macroeconomic variables and saving culture, do not vary among individuals with different demographic characteristics. (see Table 15-19 in appendix)

\section{Recommendations}

Based on the findings of the study the following recommendations are forwarded:

$>$ Among customer specific variables trust and saving habit of depositors' are found to be significant. Lack of trust on banking business may leads to bank run and insolvency therefore it is advisable for banks to 
design a mechanism that maintains customers' trust on banking system depending on depositors' demographic characteristics. In addition saving habit of depositors is also determinant factor to mobilize significant amount of deposit, thus promoting this habit in collaboration with other stakeholders is demanded.

$>$ Among bank specific factors branch expansion, variety of service offered and confidentiality of customers' are found to be significant to determine deposit mobilization. Among these respondents provide high score to confidentiality of information kept. In Ethiopian context branching is widely conducted by all banks in the industry. This should be coupled with better and diversified bank service to customers to have better share of deposit market.

$>$ Interest and inflation rates are among macroeconomic variables, which are found to be significant. Deposit rate is an encouraging factor however inflation do not. In the context of Ethiopia the National Bank of Ethiopia set the minimum and maximum deposit rate. Setting this only will not be attractive unless the deposit rate offsets the inflation rate. Thus for policy makers it is advisable to manage inflation to the extent of deposit rate otherwise it is hard to mobilize savings from individuals.

\section{References}

Bryman A. (2012). Social Research Methods. (4 ${ }^{\text {th }}$ ed.).Oxford University Press, New York, USA.

Devinaga, R. (2010). Theoretical Framework of Profitability as Applied to Commercial Bank in Malaysia. European Journal of Economics, Finance and Administrative Sciences, Multimedia University, Faculty of Business and Law, Melaka, Malaysia.

Epaphra, M. (2014). Empirical Investigation of the Determinants of Tanzania's National Savings. Journal of Economics and Development Studies, 2, 223-241.

Erna Rachmawati \& Ekki Syamsulhakim. (2004). Factors Affecting Mudaraba Deposits in Ghana. Asian Jornal of Bussiness and Management Sciences, 3(03), 1-18.

Fabozzi, Frank J., Modigliani, Franco. and Jones, Frank. (2010). Foundations of Financial Markets and Institutions. ( $4^{\text {th }}$ ed.). Pearson Education Inc., USA.

Ferrouhi, Mehdi. (2017). Determinants of bank deposits in Morocco. [Online] Available: https://mpra.ub.unimuenchen.de/79075/

Herald and Heiko (2009). Deposit Interest as One of the Determining Factor for Commercial Banks Deposits. http://www.cbe.com.et background of Commercial Bank of Ethiopia.

Howells, Peter and Bain, Keith.(2007). Financial Markets And Institutions. (5 $5^{\text {th }}$ ed.). Pearson Education Limited, England.

Kelvin, A. S. (2001). The Role of Commercial Banks in Financing Growth and Economic Development in Trinidad and Tobago and the Caribbean: A Perspective From The Royal Bank of Trinidad and Tobago. Central Bank of Belize.

Kothari, C.R. (2004). Research Methodology: Methods \& Techniques. (2 ${ }^{\text {nd }}$ ed.). New Age International (P) Ltd., Publishers, India.

Larbi Siaw and Angmor Lawer. (2015). Determinants of Bank Deposits in Ghana: A Cointegration Approach. Asian Journal of Economics and Empirical Research, Vol. 2, No. 1, 1-7, 2015. [On line] available: http://asianonlinejournals.com/index.php/AJEER

Mamo Esayas Ambe. (2017). An Investigation of Determinants of Deposit Mobilization in Commercial Banks of Ethiopia. Journal of Research on Humanities and Social Sciences, Vol.7, No.19, 55-64.

Mishkin, Frederic S. and Eakins. (2012). Financial markets and institutions.( 7th ed.). The Prentice Hall series in Finance, USA.

Mohammad, N. and Mahdi, S. (2010). The Role of Inflation in Financial Repression: Evidence from Iran. Journal of World Applied Sciences 11 (6): 653-661.

N. Desinga Rao. (1975). Deposit Mobilization by Co-operative Banks: A Comparison Economic and Political Weekly No. 29, pp. 1098-1100

Nahidul Islam, Julfikar Ali and Atif Wafik. (2019). Determinants of Deposit Mobilization of Private Commercial Banks: Evidence from Bangladesh. International Journal of Business and Management Invention (IJBMI), Vol. 8, Issue 10, PP 26-33.

National Bank of Ethiopia. (2017). Annual Report 2016/17. [On line] Available: https://nbebank.com/annualreport/

National Bank of Ethiopia. (2018). Annual Report 2017/18. [On line] Available: https://nbebank.com/annualreport/

Saunders, Anthony and Cornett, M.M. (2008). Financial Institutions Management: A Risk Management Approach. ( $6^{\text {th }}$ ed.). McGraw-Hill/Irwin, New York, USA.

Shemsu Bargicho Adem. (2015). Determinants of Commercial Bank Deposits in Ethiopia: A Case Of Commercial Bank of Ethiopia. Thesis submitted to Addis Ababa University, Ethiopia. 


\section{Appendix}

Table 15: ANOVA by Age Group

\begin{tabular}{|c|c|c|c|c|c|c|}
\hline & & Sum of Squares & $\mathrm{df}$ & Mean Square & $\mathrm{F}$ & Sig. \\
\hline \multirow{3}{*}{ Branch Expansion } & Between Groups & 10.514 & 2 & 5.257 & 7.186 & $.001 * *$ \\
\hline & Within Groups & 171.911 & 235 & .732 & & \\
\hline & Total & 182.424 & 237 & & & \\
\hline \multirow{3}{*}{ Confidentiality } & Between Groups & 1.394 & 2 & .697 & 3.740 & $.025^{* *}$ \\
\hline & Within Groups & 43.783 & 235 & .186 & & \\
\hline & Total & 45.176 & 237 & & & \\
\hline \multirow{3}{*}{ Verities of Services } & Between Groups & 1.063 & 2 & .531 & 2.844 & .060 \\
\hline & Within Groups & 43.900 & 235 & .187 & & \\
\hline & Total & 44.962 & 237 & & & \\
\hline \multirow{3}{*}{ Trust as service provider } & Between Groups & 2.926 & 2 & 1.463 & 5.078 & $.007 * *$ \\
\hline & Within Groups & 67.712 & 235 & .288 & & \\
\hline & Total & 70.639 & 237 & & & \\
\hline \multirow{3}{*}{ Saving culture } & Between Groups & 1.073 & 2 & .536 & .835 & .435 \\
\hline & Within Groups & 150.982 & 235 & .642 & & \\
\hline & Total & 152.055 & 237 & & & \\
\hline \multirow{3}{*}{ Interest rate } & Between Groups & .049 & 2 & .025 & .095 & .910 \\
\hline & Within Groups & 61.110 & 235 & .260 & & \\
\hline & Total & 61.160 & 237 & & & \\
\hline \multirow{3}{*}{ Inflation } & Between Groups & 1.357 & 2 & .679 & 2.212 & .112 \\
\hline & Within Groups & 72.109 & 235 & .307 & & \\
\hline & Total & 73.466 & 237 & & & \\
\hline
\end{tabular}

Source: SPSS result from survey, 2018.

**Significant at $5 \%$ level of significance.

Table 16: ANOVA by Marital Status

\begin{tabular}{|c|c|c|c|c|c|c|}
\hline & & Sum of Squares & $\mathrm{df}$ & Mean Square & $\mathrm{F}$ & Sig. \\
\hline \multirow{3}{*}{ Branch Expansion } & Between Groups & .560 & 1 & .560 & .727 & .395 \\
\hline & Within Groups & 181.864 & 236 & .771 & & \\
\hline & Total & 182.424 & 237 & & & \\
\hline & Between Groups & 3.060 & 1 & 3.060 & 17.144 & $.000 * *$ \\
\hline \multirow[t]{3}{*}{ Confidentiality } & Within Groups & 42.117 & 236 & .178 & & \\
\hline & Total & 45.176 & 237 & & & \\
\hline & Between Groups & 1.402 & 1 & 1.402 & 7.596 & $.006 * *$ \\
\hline \multirow[t]{3}{*}{ Verities of Services } & Within Groups & 43.560 & 236 & .185 & & \\
\hline & Total & 44.962 & 237 & & & \\
\hline & Between Groups & 4.644 & 1 & 4.644 & 16.606 & $.000 * *$ \\
\hline \multirow[t]{3}{*}{ Trust as service provider } & Within Groups & 65.995 & 236 & .280 & & \\
\hline & Total & 70.639 & 237 & & & \\
\hline & Between Groups & .003 & 1 & .003 & .005 & .945 \\
\hline \multirow[t]{3}{*}{ Saving culture } & Within Groups & 152.052 & 236 & .644 & & \\
\hline & Total & 152.055 & 237 & & & \\
\hline & Between Groups & .017 & 1 & .017 & .066 & .798 \\
\hline \multirow[t]{3}{*}{ Interest rate } & Within Groups & 61.143 & 236 & .259 & & \\
\hline & Total & 61.160 & 237 & & & \\
\hline & Between Groups & .018 & 1 & .018 & .059 & .809 \\
\hline \multirow[t]{2}{*}{ Inflation } & Within Groups & 73.448 & 236 & .311 & & \\
\hline & Total & 73.466 & 237 & & & \\
\hline
\end{tabular}

Source: SPSS result from survey, 2018. 
Table 17: ANOVA by Occupation

\begin{tabular}{|c|c|c|c|c|c|c|}
\hline & & Sum of Squares & $\overline{d f}$ & Mean Square & $\bar{F}$ & Sig. \\
\hline \multirow{4}{*}{ Branch Expansion } & Between Groups & 46.525 & 4 & 11.631 & 19.942 & $.000 * *$ \\
\hline & Within Groups & 135.899 & 233 & .583 & & \\
\hline & Total & 182.424 & 237 & & & \\
\hline & Between Groups & .673 & 4 & .168 & .880 & .476 \\
\hline \multirow[t]{3}{*}{ Confidentiality } & Within Groups & 44.504 & 233 & .191 & & \\
\hline & Total & 45.176 & 237 & & & \\
\hline & Between Groups & 4.293 & 4 & 1.073 & 6.149 & $.000 * *$ \\
\hline \multirow[t]{3}{*}{ Verities of Services } & Within Groups & 40.669 & 233 & .175 & & \\
\hline & Total & 44.962 & 237 & & & \\
\hline & Between Groups & 11.359 & 4 & 2.840 & 11.161 & $.000 * *$ \\
\hline \multirow[t]{3}{*}{ Trust as service provider } & Within Groups & 59.280 & 233 & .254 & & \\
\hline & Total & 70.639 & 237 & & & \\
\hline & Between Groups & 3.168 & 4 & .792 & 1.240 & .295 \\
\hline \multirow[t]{3}{*}{ Saving culture } & Within Groups & 148.886 & 233 & .639 & & \\
\hline & Total & 152.055 & 237 & & & \\
\hline & Between Groups & .921 & 4 & .230 & .891 & .470 \\
\hline \multirow[t]{3}{*}{ Interest rate } & Within Groups & 60.239 & 233 & .259 & & \\
\hline & Total & 61.160 & 237 & & & \\
\hline & Between Groups & 1.104 & 4 & .276 & .888 & .472 \\
\hline \multirow[t]{2}{*}{ Inflation } & Within Groups & 72.363 & 233 & .311 & & \\
\hline & Total & 73.466 & 237 & & & \\
\hline
\end{tabular}

Source: SPSS result from survey, 2018.

**Significant at 5\% level of significance.

Table 18: ANOVA by Education

\begin{tabular}{|c|c|c|c|c|c|c|}
\hline & & Sum of Squares & df & Mean Square & $\mathrm{F}$ & Sig. \\
\hline \multirow{3}{*}{ Branch Expansion } & Between Groups & 94.102 & 3 & 31.367 & 83.104 & $.000 * *$ \\
\hline & Within Groups & 88.322 & 234 & .377 & & \\
\hline & Total & 182.424 & 237 & & & \\
\hline \multirow{3}{*}{ Confidentiality } & Between Groups & 7.298 & 3 & 2.433 & 15.029 & $.000 * *$ \\
\hline & Within Groups & 37.878 & 234 & .162 & & \\
\hline & Total & 45.176 & 237 & & & \\
\hline \multirow{3}{*}{ Verities of Services } & Between Groups & 4.584 & 3 & 1.528 & 8.854 & $.000 * *$ \\
\hline & Within Groups & 40.379 & 234 & .173 & & \\
\hline & Total & 44.962 & 237 & & & \\
\hline \multirow{3}{*}{ Trust as service provider } & Between Groups & 19.161 & 3 & 6.387 & 29.033 & $.000 * *$ \\
\hline & Within Groups & 51.478 & 234 & .220 & & \\
\hline & Total & 70.639 & 237 & & & \\
\hline \multirow{3}{*}{ Saving culture } & Between Groups & 2.226 & 3 & .742 & 1.159 & .326 \\
\hline & Within Groups & 149.829 & 234 & .640 & & \\
\hline & Total & 152.055 & 237 & & & \\
\hline \multirow{3}{*}{ Interest rate } & Between Groups & 1.834 & 3 & .611 & 2.412 & .068 \\
\hline & Within Groups & 59.325 & 234 & .254 & & \\
\hline & Total & 61.160 & 237 & & & \\
\hline \multirow{3}{*}{ Inflation } & Between Groups & 1.253 & 3 & .418 & 1.354 & .258 \\
\hline & Within Groups & 72.213 & 234 & .309 & & \\
\hline & Total & 73.466 & 237 & & & \\
\hline
\end{tabular}

Source: SPSS result from survey, 2018. 
Table 19: ANOVA Years as Customer of CBE

\begin{tabular}{|c|c|c|c|c|c|c|}
\hline & & Sum of Squares & $\mathrm{df}$ & Mean Square & $\mathrm{F}$ & Sig. \\
\hline \multirow{3}{*}{ Branch Expansion } & Between Groups & 10.514 & 2 & 5.257 & 7.186 & $.001 * *$ \\
\hline & Within Groups & 171.911 & 235 & .732 & & \\
\hline & Total & 182.424 & 237 & & & \\
\hline & Between Groups & 1.394 & 2 & .697 & 3.740 & $.025 * *$ \\
\hline \multirow[t]{3}{*}{ Confidentiality } & Within Groups & 43.783 & 235 & .186 & & \\
\hline & Total & 45.176 & 237 & & & \\
\hline & Between Groups & 1.063 & 2 & .531 & 2.844 & .060 \\
\hline \multirow[t]{3}{*}{ Verities of Services } & Within Groups & 43.900 & 235 & .187 & & \\
\hline & Total & 44.962 & 237 & & & \\
\hline & Between Groups & 2.926 & 2 & 1.463 & 5.078 & $.007 * *$ \\
\hline \multirow[t]{3}{*}{ Trust as service provider } & Within Groups & 67.712 & 235 & .288 & & \\
\hline & Total & 70.639 & 237 & & & \\
\hline & Between Groups & 1.073 & 2 & .536 & .835 & .435 \\
\hline \multirow[t]{3}{*}{ Saving culture } & Within Groups & 150.982 & 235 & .642 & & \\
\hline & Total & 152.055 & 237 & & & \\
\hline & Between Groups & .049 & 2 & .025 & .095 & .910 \\
\hline \multirow[t]{3}{*}{ Interest rate } & Within Groups & 61.110 & 235 & .260 & & \\
\hline & Total & 61.160 & 237 & & & \\
\hline & Between Groups & 1.357 & 2 & .679 & 2.212 & .112 \\
\hline \multirow[t]{2}{*}{ Inflation } & Within Groups & 72.109 & 235 & .307 & & \\
\hline & Total & 73.466 & 237 & & & \\
\hline
\end{tabular}

Source: SPSS result from survey, 2018.

$* *$ Significant at $5 \%$ level of significance. 